\title{
Dinâmica imobiliária da habitação em bairros adjacentes ao centro de Porto Alegre/RS
}

\author{
Real estate dynamics in neighborhoods adjacent to \\ downtown Porto Alegre, state of Rio Grande do Sul
}

Nicole Leal de Almeida [I] Heleniza Ávila Campos [II]

\section{Resumo}

As transformações urbanas oriundas do processo de financeirização da habitação influenciaram na dinâmica espacial das metrópoles brasileiras. Desde então, setores das grandes cidades brasileiras com terras passíveis de incorporação de novos produtos imobiliários ou suscetíveis a projetos de requalificação urbana tornaram-se alvo de ações intensivas por parte de incorporadoras imobiliárias. Contribuíram para ações similares os investimentos em infraestrutura que integraram os projetos de interesse social, por parte do Estado, em áreas pouco atraentes ao capital imobiliário. Este artigo tem como objetivo discutir a atuação do setor imobiliário no IV Distrito de Porto Alegre, entre 2007 e 2016, através da compreensão dos efeitos dos arranjos imobiliários no espaço de moradia e na tentativa vigente de ressignificar esse setor.

Palavras-chave: bairros adjacentes ao centro; financeirização; dinâmica do setor imobiliário; reestruturação urbana.

\begin{abstract}
Urban transformations resulting from the housing financialization process have influenced the spatial dynamics of Brazilian metropolises. Since then, sectors of large Brazilian cities with land that can be used for developing new real estate products or susceptible to urban upgrading projects have become the target of intensive actions by real estate developers. Investments in infrastructure that have integrated the State's social interest projects into areas unattractive to real estate capital have contributed to similar actions. The article aims to discuss the action of the real estate sector in the IV District of Porto Alegre between 2007 and 2016 by understanding the effects of real estate arrangements on housing space and on the current attempt to re-signify this sector.
\end{abstract}

Keywords: neighborhoods adjacent to the downtown area; financialization; real estate sector dynamics; urban restructuring. 


\section{Introdução}

A transformação da habitação em mercadoria e ativo financeiro não é resultado de uma dinâmica recente, visto que a construção da cultura da casa própria permeia boa parte das políticas habitacionais brasileiras. Entretanto, na versão contemporânea, a cultura da casa própria ganhou força através da ampliação do crédito habitacional e da securitização, que viabilizaram a entrada das classes de média e baixa renda no mercado. Ressalta-se, assim, um problema social real - a falta de moradias dignas para a população de baixa renda - para responder aos interesses capitalistas. Isso se deu em um contexto global de "financeirização da habitação" e de tomada da incorporação residencial pelo mercado financeiro. Além disso, o incentivo à produção e à aquisição de bens duráveis através de isenções e subsídios, no Brasil, fez com que trabalhadores e pequenos empresários figurassem como a "nova classe média". Estrato social que ajudou a construir boa parte das demandas que correspondem à ampliação do mercado privado de habitação (Rolnik, 2015; Fix, 2011).

Nesse contexto, as mudanças no mercado imobiliário, sobretudo sua vinculação aos mecanismos de financeirização do setor da Habitação, através da concessão de crédito e de isenções que ampliaram a possibilidade de financiamento, fizeram com que a demanda por terras pelo mercado imobiliário aumentasse consideravelmente. Historicamente, a política habitacional brasileira é marcada por mecanismos que favorecem alguns atores que participam da produção do espaço urbano e metropolitano, mormente a atuação do mercado privado. As origens das confluências entre o
Estado e o mercado imobiliário privado dão-se, de forma mais evidente, a partir dos anos 1990, com a influência de práticas neoliberais de economia política no País (Rolnik, 2015) e são reforçadas pelos programas habitacionais estruturados nos governos seguintes, especialmente os governos de Lula (2003-2010).

Com a expansão das áreas de atuação do mercado imobiliário, particularmente a partir de 2007 e 2008, ${ }^{1}$ no Brasil alguns setores da cidade se tornaram objeto de especulação, em especial áreas com potencial de valorização. Tendo em vista que o mercado é um dos principais promotores de habitação, a oferta - em qualquer tempo - será priorizada em áreas da cidade que esses agentes julgarem lucrativas (Cardoso e Aragão, 2011). Dessa forma, destacam-se, aqui, os interesses do mercado imobiliário em relação às zonas adjacentes ao centro, que passaram por um processo de desindustrialização e degradação de seu ambiente construído.

Diferentemente de áreas em que o solo é barato pela carência de infraestrutura urbana, mas que estão distantes do centro comercial e histórico, as zonas adjacentes ao centro passam por um processo de desvalorização de seu patrimônio construído, pelo descompasso entre as atuais formas de uso e ocupação de seu solo. E, geralmente, estão vinculadas a comunidades carentes e com baixa capacidade de barganha sobre seu território, ao passo que o crescimento urbano é estimulado em outros setores da cidade. Singer (2017) aponta que uma estratégia corrente para conter a deterioração desses setores da cidade é a intervenção do Estado, através de desapropriação e programas de renovação. No entanto, essas ações, que se inclinam à valorização da área, acabam por prejudicar os antigos moradores; 
enquanto grandes empresas construtoras e incorporadoras, com condições de se anteciparem à valorização adquirindo lotes, tendem a conseguir resultados lucrativos na venda de imóveis após as benfeitorias.

Este artigo pretende, portanto, discutir a participação de empresas incorporadoras em áreas próximas ao centro, identificadas pelo mercado e pelo Estado como zonas decadentes e marginalizadas, e o tensionamento entre estratos de sua população moradora mais vulnerável e empobrecida. Como objeto de análise foi utilizada a área adjacente ao centro de Porto Alegre/RS, conhecida como IV Distrito, composta pelos bairros Floresta, São Geraldo, Navegantes, Farrapos e Humaitá. A área de estudo em questão foi determinante para o desenvolvimento socioespacial de Porto Alegre, dada sua localização estratégica em relação aos principais acessos à cidade e sua proximidade ao centro histórico, o que influenciou sua ocupação pelo parque industrial no início do século XX. Entretanto, a área passou por um processo de obsolescência e degradação e tornou-se objeto de estratégias de reconversão econômica e reestruturação através do potencial de participação do capital imobiliário e financeiro.

É possível pressupor que, a partir de investimentos em infraestrutura e obras de grande porte promovidas pela Prefeitura $\mathrm{Mu}$ nicipal de Porto Alegre (PMPA), o mercado imobiliário identificou, na área, a possibilidade de agregar valor a terrenos e implantar novos produtos imobiliários. Com isso, moradores locais de baixa renda que ocupavam espaços até então obsoletos do ponto de vista econômico e funcional se encontram pressionados física e juridicamente; seja através de ações de reintegração de posse ou despejo, seja pelas crescentes demandas de novas construções do mercado imobiliário. A partir dessas análises, pretende-se contribuir para a compreensão da atuação de grandes empresas em bairros adjacentes ao centro e de que forma, no contexto atual de crise do financiamento habitacional, as empresas buscam manter os padrões de reestruturação produtiva desses territórios.

A estrutura do artigo é composta por quatro partes, além de introdução e considerações finais. A primeira destina-se à caracterização da área adjacente ao centro e explana de que modo ela se apresenta atrativa ao mercado imobiliário. A segunda parte apresenta os antecedentes históricos de caracterização da área em estudo. Nela se pretende identificar os processos de consolidação (de sua criação até os anos 1970), obsolescência (a partir dos anos 1970) e degradação da área (entre os anos 1970 e 1990), ou seja, os processos que antecederam a reestruturação da lógica imobiliária da área. A terceira parte pretende apresentar como se deu o incentivo à entrada do mercado imobiliário no território a partir de 2007. Em seguida, na quarta parte, é apresentada uma análise sobre a distribuição dos produtos imobiliários na área do IV Distrito e seus desdobramentos diretos para a população local, com especial enfoque às atuais movimentações de investimentos e à construção de novos empreendimentos pelo mercado imobiliário.

\section{Obsolescência e degradação em zonas adjacentes ao centro}

Os estudos referentes às estruturas internas da cidade necessitam recorrentemente de revisões e releituras em função das contínuas 
transformações e ressignificações que os espaços assumem ao longo do tempo. A importância da área central e de áreas a ela adjacentes persiste nas cidades brasileiras, com questões que precisam ser consideradas, como processos espaciais de obsolescência e requalificação funcional e econômica. De fato, as áreas adjacentes ao centro são atrativas ao mercado imobiliário devido ao seu potencial construtivo, à existência de infraestrutura e à sua localização privilegiada para a instalação de novos empreendimentos. Cabe destacar que, apesar de os estudos acerca da estrutura interna da cidade a partir de padrões espaciais não serem recentes, faz-se necessário retomá-los para compreender o desenvolvimento de alguns setores na cidade, particularmente, nesse caso, a área adjacente ao centro.

$A$ área adjacente ao centro é entendida, por alguns autores, como uma zona de transição entre o centro comercial e a zona de predominância mais residencial. Foram desenvolvidos modelos e estudos por pesquisadores, desde a década de 1920, que mostram que os usos do solo urbano não se distribuem aleatoriamente. Burgess, segundo Strohaecker (1988), classificou as áreas em questão como zonas de transição. Elas são caracterizadas pelo uso misto, com indústrias, comércios e residências; o uso residencial, por sua vez, é reduzido e acaba sendo apropriado por pessoas de baixa renda e grupos vulneráveis. 0 modelo de estudo de Burgess acredita que, devido à proximidade com o centro, essa zona se torna atrativa para comércios e serviços e que acabaria, com o tempo, absorvendo os excedentes da área central.

Strohaecker (1988), no entanto, destaca que a descentralização e a verticalização da zona central frustraram as expectativas de
Burgess de que a zona de transição seria "invadida" por comércios e serviços, dada a proximidade com a zona central. 0 que se observou, ao contrário do que Burgess acreditava, foi a dificuldade de adaptação das estruturas físicas, resultando em problemas relacionados ao envelhecimento delas. São essas áreas que possuem uma estrutura social e econômica sujeitas a transformações mais lentas, em geral, promovidas pelos movimentos intermitentes de desinteresse e investimento do capital imobiliário urbano que repercutem em consecutivos processos socioespaciais de degradação e revalorização, típicos das cidades capitalistas. Assim, Strohaecker (ibid.) aponta que o perfil "cristalizado" das estruturas nas chamadas, até então, "zonas de transição", torna o uso do termo "transição" inadequado. A autora ainda observa que estudos mais recentes indicam que o termo "zona periférica" ao centro se sobrepõe aos conceitos "transição", "área cinzenta" ou "zona de obsolescência", por não rotular de forma rígida, mas, sim, absorver as características delas. Contudo, considerando as discussões e a carga de significados do termo "periferia", optou-se, neste artigo, por utilizar o termo áreas adjacentes ao centro.

De modo geral, os bairros adjacentes ao centro constituem uma área de uso semi-intensivo, que comporta atividades de comércio atacadista, antigos distritos industriais com terrenos vagos e características morfológicas muito particulares, segundo Corrêa (1989). Entre elas, ainda com base no autor, no que se refere ao uso industrial, figura o recorrente abandono de estruturas e edificações quando as empresas já não são mais beneficiadas pela localização e se deparam com limitadas possibilidades de ampliação das plantas industriais. Quando se trata do uso residencial, 
por um lado, o autor observa que o setor é caracterizado por residências populares e de baixa classe média; por outro aponta que a área constitui o principal foco da política de renovação urbana, que consiste na substituição de prédios deteriorados por novos edifícios de apartamento, culminando na substituição de moradores pobres pela classe média.

A característica apontada por Corrêa (ibid.), de substituição de antigas edificações, como também dos moradores mais tradicionais, exige um tempo para se desenvolver no espaço urbano, gerando, assim, um longo período de esvaziamento social, funcional e econômico do setor, em que se manifestam a sua obsolescência e degradação. A cristalização das estruturas exige que políticas e estratégias sejam desenvolvidas, além de investimentos por parte do Estado - geralmente representado pelo poder local -, para que despertem o interesse do mercado imobiliário. Para Singer (2017), a desvalorização da área adjacente ao centro e, consequentemente, a redução do valor do solo podem também incentivar a negligência por parte dos proprietários de antigas edificações em momentos em que não há interesse do mercado imobiliário, do Estado e de outros investidores para a renovação ou requalificação urbana. Para que esses processos transformadores aconteçam, é necessária uma condição em que esses agentes sociais se sintam motivados, sendo, em geral, o Estado o articulador de ações que promovam as condições necessárias para que a área volte a ser atrativa. $\mathrm{O}$ autor coloca, ainda, que os programas de renovação urbana comumente recuperam as áreas em deterioração para o uso das camadas média ou rica e das empresas que Ihes prestam serviços.
Nesse sentido, ao observar as realidades de áreas adjacentes ao centro em grandes cidades brasileiras, verifica-se que algumas transformações, tanto na estrutura financeira do setor imobiliário, quanto nas políticas públicas de habitação, foram determinantes para viabilizar projetos de reestruturação urbana. Shimbo (2010) destaca que, em um contexto recente (2005-2010), o mercado financeiro aproximou-se do setor imobiliário no Brasil. Com isso, empresas que antes eram familiares se abriram ao mercado financeiro e passaram a disponibilizar ações no mercado nacional e internacional, potencializando a abertura de capital de empresas na bolsa de valores, o que impulsionou o processo de financeirização imobiliária. A aproximação entre os mercados financeiro e imobiliário foi orientada por um conjunto de medidas por parte do governo federal nos últimos dez anos, permitindo maior segurança jurídica para incorporadores, construtores e investidores, enquanto medidas regulatórias estimularam a produção de habitação via mercado, segundo Shimbo (ibid.).

$O$ pacote Minha Casa Minha Vida, anunciado em 2009, teve papel definitivo na solidificação das transformações no mercado imobiliário e na paisagem urbana das cidades, visto que tinha como um dos objetivos amenizar os resultados da crise financeira de 2008 (Fix, 2011). Além disso, Shimbo (2010) aponta que o programa pretendia "atacar" duas demandas: a geração de trabalho, através da construção civil, e o atendimento da habitação de baixa renda. Para Fix (2011), o programa, que foi elaborado sob liderança da Casa Civil e do Ministério da Fazenda, articulou um problema nacional prioritário através dos critérios do capital imobiliário. Nesse sentido, ainda com 
base em Fix (ibid.), muitas empresas indicaram o MCMV como indutor para a ampliação do seu mercado. A exemplo disso, a autora apresenta dados referentes à empresa Rossi, que aumentou de $29 \%$ para $48 \%$ o total de lançamentos em 2009, que compreendem uma classe que até então não tinha acesso à casa própria. A linha de lançamentos do segmento econômico tem definição variante, mas seus produtos costumam ter até $85 \mathrm{~m}^{2}$.

É nesse contexto que está inserido o recorte espacial analisado neste artigo. Para melhor compreender os aspectos gerais que permeiam as transformações do IV Distrito de Porto Alegre, é importante entender como se deram a consolidação do território e o processo de subutilização da área que antecedeu à reestruturação, a partir da lógica imobiliária apresentada até aqui. Sendo assim, a próxima parte tem como objetivo apresentar um panorama geral da história desse setor da cidade.

\section{Caracterização e configuração da lógica imobiliária no IV Distrito}

\footnotetext{
A história do IV Distrito apresenta processos espaciais característicos de uma área adjacente à área central. A consolidação do antigo distrito industrial de Porto Alegre/RS e de suas imediações dá-se a partir das condições favoráveis e estratégicas nas quais a cidade está inserida em relação à lógica de expansão vigente nos séculos XVIII e XIX. Tanto a proximidade ao Delta do Jacuí, a norte da lagoa dos Patos, quanto a localização na entrada da cidade, às margens do Guaíba, favoreciam o transporte
}

hidroviário da produção exportada dessa região, assim como, posteriormente, o uso de linha ferroviária (Singer, 1977).

Souza e Müller (1997) reafirmam que o ciclo industrial de Porto Alegre se deu a partir da metade do século XIX, concomitantemente com a expansão da cidade, através dos seus principais eixos de acesso, sendo o principal o então Caminho Novo (posteriormente denominado rua Voluntários da Pátria). Esse eixo conectava o bairro industrial Navegantes, localizado próximo ao centro comercial de Porto Alegre, à recém-criada Colônia de São Leopoldo, em 1824, área anteriormente ocupada por indígenas Kaingang e Carijós, que foi destinada aos imigrantes alemães pelo governo imperial brasileiro, com a proposta de ocupação e expansão do seu território.

Nesse sentido, além da localização próxima ao principal eixo estruturador da cidade, que facilitava o acesso ao centro e era também passagem dos viajantes, destacam-se as suas características físico-naturais (proximidade a grandes cursos d'água e topografia plana), adequadas à ocupação industrial. Como resultado, consolidaram-se não só o Caminho Novo, mas também parte do que hoje se conhece como os bairros Floresta, São Geraldo e Navegantes, ${ }^{2}$ identificados como setor industrial da cidade (Fernandes, 2014; Souza e Müller, 1997). A Figura 1 destaca, em cinza mais escuro, a localização desses bairros.

Com a expansão de instalações industriais e o crescente fluxo migratório europeu, a cidade de Porto Alegre apresentou entre 1872 e 1890 um grande crescimento demográfico, que resultou na escassez de moradias populares que atendessem às demandas do mercado. Nesse contexto, foi fundada, em 1892, 
Figura 1 - Mapa de localização do IV Distrito - 2021

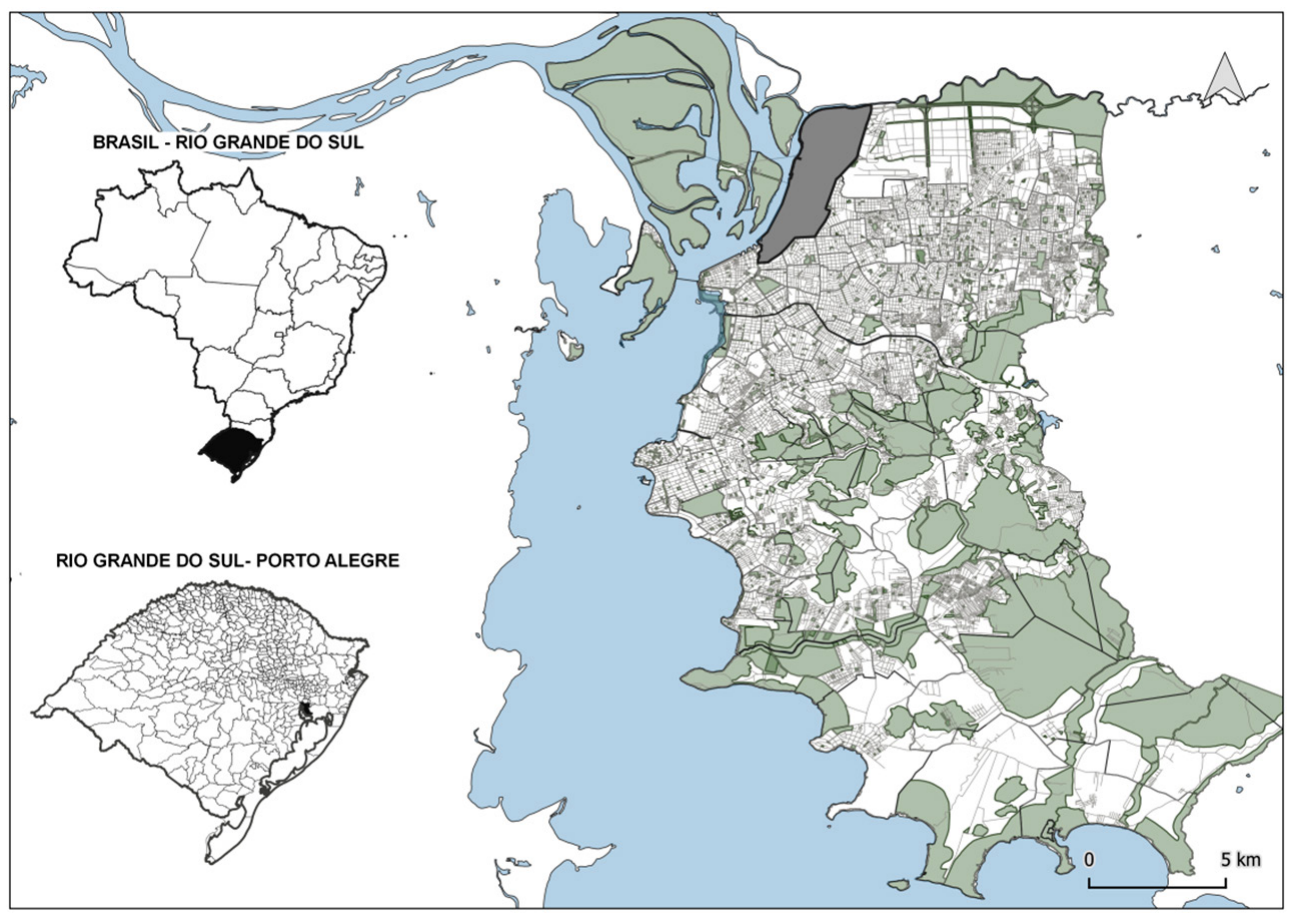

Elaborado por Nicole Leal de Almeida, em 2021.

a Companhia Territorial Porto Alegrense, responsável pelo loteamento da cidade, atuando principalmente na sua zona norte, mais especificamente nos bairros Navegantes, São Geraldo e parte dos bairros São João e Higienópolis. Os bairros Navegantes e São Geraldo, por se constituírem juntos em região de cotas topográficas mais baixas, com tendências alagadiças e mais distantes do centro, foram destinados aos imigrantes que buscavam se estabelecer nas proximidades de fábricas localizadas na região. (Souza e Müller, 1997; Strohaecker, 2005).
Esse cenário social e econômico, portanto, constituiu a região, com traçado urbano mais reticulado, articulando os grandes prédios das fábricas e galpões industriais às ocupações de uso residencial, voltadas principalmente aos operários e imigrantes, até aproximadamente 1940. A grande enchente de 1941, que provocou inundações e prejuízos para a cidade de Porto Alegre, foi o primeiro estímulo ao deslocamento das indústrias para localidades mais afastadas das águas e próximas aos eixos viários. Os impactos causados 
pela enchente marcam o início do processo de decadência da região, visto que muitas edificações e galpões industriais ficaram inutilizados e foram abandonados (Titton, 2012). Além disso, a associação de zonas baixas e propensas a alagamentos com atividades rejeitadas fez com que o setor se tornasse cada vez menos atrativo ao mercado imobiliário (Mattar, 2010).

As mudanças decorrentes do crescimento de Porto Alegre foram também transformando a ocupação do IV Distrito. Os sucessivos aterros nas margens do Guaíba, bem como a finalização da construção do Cais do Porto (1911-1962), obras importantes para contenção das águas e proteção contra enchentes, acabaram por isolar a cidade do rio Guaíba. Outras obras importantes, como a construção da avenida Farrapos (1940) e o cruzamento entre as ruas Voluntários da Pátria e Conceição, também colaboraram para a segregação dessa parte da cidade (Mattar, 2010; Titton 2012).

No que tange à legislação urbana, o primeiro Plano Diretor de Porto Alegre (lei n. 2046/1959, com alteração na lei n. 2330/1961) buscava conter a verticalização e o exclusivo uso industrial da área, destinado à boa parte dos bairros Floresta, Navegantes e São Geraldo, o que também contribuiu para o seu esvaziamento. Essa orientação se manteve no Plano Diretor de Desenvolvimento Urbano (PDDU) de 1979 (Titton, 2012). Em direção oposta, o governo do estado do Rio Grande do Sul voltava-se para a estruturação de uma política de desconcentração industrial. Ou seja, um processo de deslocamento das plantas industriais, impulsionado pela aglomeração populacional e pela metropolização na década de 1970.
Em decorrência dessa desconcentração, foram implantados distritos industriais ao longo da BR-290 (sentido Leste-Oeste), afastando-os da região do IV Distrito, que já se encontrava totalmente inserida no tecido urbano. Os projetos de loteamentos industriais em novas áreas, com incentivo do Governo Estadual, por meio da desapropriação de áreas e garantia da infraestrutura para o funcionamento das empresas, implicaram o deslocamento de muitas empresas e indústrias da zona Norte de Porto Alegre, que alegavam não ter condições de expansão dentro dos limites da capital (Fernandes, 2014). O resultado desse processo foi, portanto, o esvaziamento do primeiro setor industrial da cidade, por parte não só da indústria, mas também da classe operária residente nas redondezas das empresas em que trabalhava. Com isso, não só os antigos galpões e edificações industriais ficaram obsoletos, mas também atividades de comércio e serviços fecharam suas portas, na medida em que a prática cotidiana, até então estabelecida, foi sendo descaracterizada.

Atualmente o antigo distrito industrial é alvo de diversas propostas de revitalização que diferem quanto ao recorte espacial de intervenção. Tais propostas tendem a dois posicionamentos: a) desconsiderar as práticas espaciais distintas existentes nesses bairros, imputando, ao antigo distrito, uma identidade próxima às novas formas de reconversão econômica, principalmente vinculadas à economia criativa e cultural; b) dividir o território do IV Distrito em três áreas: os bairros Floresta e São Geraldo, mais próximos ao centro e a bairros de classe média e média alta e, portanto, com maior potencial para atrair investidores; o bairro Navegantes, considerado como uma área de 
transição com potencial cultural religioso de distintas matrizes religiosas, sendo privilegiadas pelas propostas, sobretudo as festividades relacionadas à Igreja Católica; por fim, os bairros Farrapos e Humaitá, que, apesar de serem predominantemente residenciais, possuem diferenças marcantes entre si. Dessa forma, o que se apresenta no setor é a conformação de diferentes espaços e formas de apropriação de seu uso do solo, evidenciadas à medida que verificamos práticas espaciais distintas, por parte tanto de agentes hegemônicos, como contra-hegemônicos.

Todavia, dada a complexidade das práticas espaciais existentes no conjunto do IV Distrito, os esforços desta pesquisa foram concentrados na análise da dinâmica do mercado imobiliário. A ênfase é dada ao período entre 2007 e 2016, que reverbera nas proposições recentes. Estas, por sua parte, pautadas em estratégias de image-making - nos termos de Arantes (2013) -, sobretudo nos bairros mais próximos da área central, ou seja, Floresta e São Geraldo. No bairro Farrapos predomina a ocupação de famílias vulneráveis com alto grau de tensionamento jurídico com o poder público municipal sobre sua permanência no local; em Humaitá, alvo da ação intensiva de empresas imobiliárias, destaca-se a produção de habitação para o segmento de renda média. Na parte a seguir serão discutidas as primeiras iniciativas de reestruturação do IV Distrito, sob a tutela da prefeitura municipal de Porto Alegre articulada a interesses do capital imobiliário.

\section{As primeiras iniciativas de reestruturação urbana da área}

Dado o contexto de declínio funcional da área adjacente ao centro, no processo de desenvolvimento socioespacial da cidade de Porto Alegre, cabe agora buscar compreender como se deram as primeiras tentativas de transformação desse setor da cidade através da ressignificação dos seus espaços. Como o setor em análise apresenta ampla infraestrutura urbana, além de localização privilegiada - principal agregador de valor ao solo urbano -, parte-se da tentativa de reinserção do IV Distrito no circuito econômico de Porto Alegre em meados dos anos 1990.

A reestruturação do território tem importância não apenas local (município de Porto Alegre), mas também metropolitana e regional; vinculada às necessidades e condições de articulação da cidade com o mercado econômico global. Isso se dá pelos diversos modais de transporte que circulam próximo ou dentro do setor. Além da proximidade com equipamentos logísticos importantes, tais como a região portuária, o aeroporto internacional Salgado Filho e o trem metropolitano Trensurb, a área ainda possui conexões importantes através do fácil acesso às principais rodovias de entrada e saída da capital. Contudo, apesar das potencialidades relacionadas à localização, acessibilidade e infraestrutura, observa-se que o desgaste e obsolescência dos 
usos e edificações sempre foram dificultadores de negócios imobiliários das glebas e terrenos abandonados do setor. Nesse sentido, têm sido desenvolvidos projetos de reestruturação das suas funções e usos.

Do ponto de vista do cenário nacional, segundo Rolnik, Cymbalista e Nakano (2011), é importante destacar que, apesar do reconhecimento da função social da propriedade pela Constituição de 1988, no setor imobiliário e na construção de políticas habitacionais no País, as décadas de 1980 e 1990 foram períodos de escassez de investimentos. Isso se deu em função dos limitados recursos voltados à produção de moradias e ao endividamento público, além da paralisação do BNH (1976-1986), o que culminou em um período de retração na atividade imobiliária e no financiamento habitacional. Esse cenário começa a mudar a partir da metade dos anos 1990, quando, além do empreendedorismo urbano, sob a perspectiva neoliberal como resposta à crise econômico-política, foram executadas reformas no modelo de regulação do crédito habitacional referentes à estrutura do capital de empresas envolvidas no mercado imobiliário (Rolnik, 2015).

Durante o governo de Fernando Henrique Cardoso (1995-2002), houve a montagem do Sistema Financeiro Imobiliário, que captava recursos no mercado imobiliário e tinha, como principal diferença em relação aos sistemas anteriores, o crédito ao usuário final. Em Porto Alegre, por sua vez, aconteceu, em 1997, a 1으 Conferência Municipal de Habitação, que objetivava a produção de habitação integrada com políticas de acesso e participação popular.

Entretanto, as questões habitacionais não foram prioridade nas pautas da prefeitura municipal, que trataram da reestruturação dos bairros adjacentes ao centro de Porto Alegre durante os anos 1990. Com o fim do BNH, a captação de recursos para a construção de habitações de interesse social na metrópole, entre 1990 e 2000, deu-se através do Habitar Brasil/Bid e do Fundo Financeiro para Desenvolvimento da Bacia do Prata (Fonplata). Por meio desses recursos, foi implementado o Programa de Entrada da Cidade (Piec) que contemplou a região Humaitá/Navegantes com habitações e obras de infraestrutura. Entretanto, foi apenas em 2005 que o programa recebeu o impulso necessário para ser executado. As ações desenvolvidas naquele momento buscavam minimizar os anos de restrição do uso do zoneamento prioritariamente industrial e almejavam a regeneração urbana.

Entre as ações que buscavam a reconversão econômica está o projeto do Parque Tecnológico Urbano (PTU), que teve início em 1995 e buscava transformar, em particular, o espaço do antigo IV Distrito em um polo de inovação tecnológica. Os motivos que levaram à escolha da área foram a concentração de empresas do nicho eletrônico e alta tecnologia e a presença de áreas ociosas e de baixo custo, além das já mencionadas vantagens locacionais. Titton (2012) afirma que a definição do IV Distrito como localidade ideal para instalação do PTU se deu após consultoria com o arquiteto espanhol Josep Maria Llop Tomé e com o economista Rafael Gonzalez Tormo, diretor do projeto 22@ Barcelona. 0 objetivo era transformar a área em um corredor de urbanidade, delimitado entre as avenidas Sertório, Farrapos e Castelo Branco. Porém, o programa acabou sendo extinto mediante dificuldades encontradas em relação à agilidade e à origem dos investimentos necessários e teve suas atividades encerradas definitivamente em 2005 com a troca de governo municipal ${ }^{3}$ (ibid.). 
Nos anos seguintes, outras ações foram desenvolvidas na tentativa de dinamizar a área. Entre 1998 e 2000 foram realizados estudos para elaboração do Relatório “Projetos Integrados, Modernização Produtiva e Inovação Tecnológica: 0 4을istrito de Porto Alegre", desenvolvido pela prefeitura municipal de Porto Alegre. O projeto tinha entre as suas pretensões estabelecer a revitalização urbana e a reconversão econômica do IV Distrito e constatou que, para tanto, seriam necessárias mudanças estruturais de saneamento básico, mobilidade urbana e reversão da imagem do setor, através de investimentos no espaço público que constituíssem um novo grau de urbanidade. 0 referido relatório também aponta para a necessidade de valorização do patrimônio cultural, densificação e miscigenação do uso do solo, com atenção às questões sociais, como a situação dos papeleiros localizados na região e combate às drogas (Albano, 2015).

0 já citado Piec teve seu contrato assinado em 2001, e as obras foram iniciadas em 2005. Os recursos destinados ao programa foram estimados em 55 milhões de dólares e contemplavam, além dos projetos de habitação de interesse social, infraestrutura viária, valorização paisagística e trabalho social (PMPA, 2009). A população-alvo do Piec era constituída por 3.775 famílias de moradores originários de assentamentos precários localizados na área de intervenção do projeto. Dessa forma, 3.061 famílias foram contempladas com novas unidades habitacionais, 416 tiveram seus lotes urbanizados e 298 tiveram complementação de infraestrutura em seus lotes (Miron, 2008). Ainda com base em Miron (ibid.), esses Empreendimentos Habitacionais de Interesse Social (EHIS) propostos pelo Piec, retiveram $73 \%$ de permanência nos empreendimentos avaliados pela autora. Apesar da dificuldade de identificar as expectativas não atendidas, entre as razões mais frequentes para a não permanência estão problemas de adaptação ao projeto e o pagamento das taxas de uso e ocupação das unidades habitacionais; problemas com a vizinhança; e a violência também figura como influenciadora da evasão. $A$ autora observa também que parte dos problemas de adaptação dos moradores ao projeto implementado está relacionada à atividade de geração de renda das famílias. Muitas das contempladas têm como principal fonte de renda a reciclagem de rejeitos e utilizam cavalos, carroças e carrinhos, o que evidencia a falta de integração entre os projetos habitacionais e as ações de geração de trabalho e renda, segundo Miron (ibid.).

O ponto-chave de transformação na área tem como marco a definição, em 2007, de Porto Alegre como uma das capitais que sediariam a Copa de 2014. Com isso, alguns projetos de infraestrutura e empreendimento foram propostos para o evento e para promover a reestruturação da região, tendo em destaque a Arena do Grêmio Foot-Ball Porto-Alegrense, complexo esportivo inaugurado em 2012 e localizado nas proximidades das EHIS implantadas pelo Piec. O projeto da Arena foi aprovado pelos órgãos reguladores como projeto de caráter excepcional, com a justificativa de que uma obra desse porte agregaria valor ao entorno e à cidade como um todo. 0 projeto prometia, além da própria Arena, um conjunto habitacional de $78.500 \mathrm{~m}^{2}$ composto por sete torres, um centro empresarial de 439.000 $\mathrm{m}^{2}$, um shopping center, um centro de eventos e um hotel. As sete torres que compõem o conjunto habitacional estão impedidas por decisões judiciais de receberem o Habite-se da 
prefeitura do município; já os projetos comerciais, até a data desta pesquisa, não haviam sido concluídos.

Naquele momento houve uma mudança nas operações imobiliárias nas imediações da Arena e, consequentemente, nas áreas de habitação de interesse social. Com a entrada de investimentos advindos do Piec e, em especial, com a pretensão do valor agregado das obras da Arena, a área ganhou potencial especulativo. Em grande parte, a especulação foi impulsionada por uma narrativa do capital imobiliário aliado ao capital financeiro, que produziu espaços a serem consumidos como mercadoria por uma população alheia aos espaços de moradia do seu entorno. Isso se viabilizou a partir da entrada de empresas incorporadoras no mercado de ações, gerando condições para captação de recursos para construção de empreendimentos que viriam a ser financiados, segundo Shimbo (2010).

Além disso, Shimbo (ibid., p. 117) observa que, entre 2004 e 2008, "houve estabilização e crescimento da economia brasileira e aumento do poder de consumo da população", em decorrência do aumento do número de "sujeitos passíveis de obterem créditos, uma nova faixa de demanda habitacional foi aberta e pode ser amortecida pelo mercado imobiliário". Entretanto, é necessário ressaltar que o aumento de sujeitos passíveis de crédito, e, por consequência, o aumento das demandas do mercado, não resulta na diminuição da segregação e no déficit habitacional. Como a autora apresenta em sua pesquisa, o segmento econômico em ascensão, naquele período, não corresponde ao déficit de moradias do País. $O$ déficit habitacional corresponde, em maior parte, à população com renda familiar de até 3 salários-mínimos (SM), sendo a população com renda acima de $5 \mathrm{SM}$ uma pequena parcela do déficit; porém, é justamente essa parcela atendida pelo segmento econômico. Esse descompasso é evidenciado quando se analisam a renda média familiar das pessoas em situação de vulnerabilidade e as atendidas pelos empreendimentos de segmento econômico no entorno da Arena, conforme será visto adiante.

No que se refere à implantação do complexo da Arena, a integração entre os setores esportivo, comercial e torres habitacionais no entorno da área, com grande número de famílias em situação de vulnerabilidade, traz à tona a complexidade das dinâmicas imobiliárias. Para Rolnik (2015), essa aproximação retrata os pontos de encontro e de conflito que ocorrem entre os setores imobiliário/financeiro e os territórios populares, aprofundando as contradições já existentes. Essas contradições, como nos lembra Carlos (2015, p. 33), esclarecem que "o choque entre o que existe e o que se impõe como novo está na base das transformações da metrópole, onde os lugares vão se integrando de modo sucessivo e simultâneo a uma nova lógica". Dessa forma, para a autora, esse processo representa a violência com a qual os processos de produção do espaço urbano são movimentados no modelo vigente, transformando a metrópole em um espaço no qual os conflitos são evidentes.

Quando se trata do território em análise, o contraste entre esses setores deixou marcas severas: em 2013, um incêndio de origem não confirmada destruiu 90 casas, atingindo aproximadamente 193 famílias na vila Liberdade, próximo ao Estádio. Essas famílias foram encaminhadas a casas de passagem, construídas nos moldes de "casas ecológicas", que teriam durabilidade máxima de cinco anos, muitas delas destruídas por um novo incêndio que 
aconteceu há pouco. Outras famílias passaram a receber o aluguel social no valor de $\mathrm{R} \$ 500,00$, cujo encerramento promoveu o retorno das famílias ao local de origem. Atualmente, 200 famílias residem na vila Liberdade, contudo, muitas delas não possuem cadastro junto ao Departamento Municipal de Habitação e, sem cadastro, não possuem garantia de receber uma solução habitacional.

Além disso, as obras de compensação relacionadas à construção do estádio na área, que deveriam ter sido realizadas em 2012 (e seguem pendentes), tiveram seus rumos mais uma vez redefinidos em dezembro de 2020 . No momento, o Ministério Público celebrou junto à OAS, atual empresa responsável pelo empreendimento, um acordo de que a empresa deveria executar as melhorias de infraestrutura no entorno do estádio. Estão previstas entre as melhorias: as obras de macrodrenagem, que visam a diminuir o impacto de alagamentos nos bairros da região, agravados pela implantação do complexo da Arena, e a construção de um quartel para a polícia militar gaúcha (MPRS, 2020).

Nesse cenário, com a entrada de novos empreendimentos imobiliários habitacionais voltados à média renda e vinculados a edificações com usos recreativos e comerciais, as necessidades de famílias vulneráveis moradoras da área foram negligenciadas. Deixando evidente a utilização da habitação como elemento de conversão econômica do uso e ocupação da área. Para Rolnik (2015), apoiada em Aalbers (2015), isso ocorre pela transformação da própria natureza e forma de ação do capitalismo contemporâneo, em que a economia política de habitação é conduzida pelo processo de "financeirização". Com a cultura da casa própria, da "socialização de créditos" e da inclusão de consumidores de classe média e baixa nos circuitos financeiros, o setor habitacional abriu novas portas para a acumulação de capital, permitindo "a livre circulação de valores através de praticamente toda a terra urbana" (Rolnik, 2015 , p. 27). Assim, a atual dominância do setor financeiro sobre o setor produtivo industrial articula a produção do espaço urbano ao plano mundial (Carlos, 2015), colocando como objeto central de acumulação de capital o consumo de novos produtos imobiliários.

Vale lembrar, no entanto, que a inserção de conjuntos habitacionais e torres corporativas na região foi proveniente, também, de iniciativas do próprio Estado e não apenas do mercado imobiliário. A revisão do Plano Diretor de Desenvolvimento Urbano e Ambiental PDDUA, em 2011, teve grande influência na transformação do uso e ocupação do solo, com grande destaque para a área do IV Distrito. $\mathrm{Na}$ ocasião da revisão do PDDUA, por solicitação de parte da comunidade local mais envolvida com a economia criativa, foi criado o Grupo de Trabalho do 4을 Distrito (PMPA, 2008) na Secretaria de Planejamento Municipal (SPM). O Grupo de Trabalho tinha como horizonte a Copa do Mundo de 2014 e objetivava formular diretrizes e projetos que colaborassem para a qualificação do espaço urbano, sob a prerrogativa do desenvolvimento sustentável e da melhor qualidade de vida na região. Sua área de atuação abarcava a estação rodoviária, a rua Voluntários da Pátria, considerada um eixo estruturador com grande potencial de renovação, seguindo até o bairro Humaitá, onde se localizava a Arena do Grêmio.

O PDDUA de 2011 apresentou significativas mudanças em relação aos planos anteriores. Uma das alterações mais expressivas na área em análise foi sua relação com a 
divisão da cidade em macrozonas, sendo as que abrangem o IV Distrito: a Macrozona 1 (Cidade Radiocêntrica), que recebe estímulo para a miscigenação do solo e proteção do patrimônio cultural; e a Macrozona 2 (Corredor de Desenvolvimento), considerada estratégica para a polarização do município, com integração entre importantes equipamentos de setores próximos ao IV Distrito, como o aeroporto e as centrais de abastecimento (Ceasa). Para a área em foco também estão definidas, no PDDUA, Áreas Especiais de Interesse Social (Aeis) e de Habitação de Interesse Social (HIS), que teriam como objetivo a inclusão de assentamentos populares autoproduzidos em áreas subutilizadas ou vazias e com infraestrutura existente. A redução da segregação socioespacial almejada com as Aeis e HIS não só não foi alcançada, como o que se verifica, conforme abordagem posterior, é o isolamento das áreas ocupadas por assentamentos precarizados em relação às áreas que se desenvolveram à lógica da dinâmica imobiliária. Os insuficientes investimentos em habitação de interesse social e na regularização dos assentamentos na área, sobretudo nos bairros Farrapos e Humaitá, criaram condições propícias para conflitos e lutas pelo território.

Com a expansão de empresas incorporadoras e a implantação de novos empreendimentos na área, as dinâmicas imobiliárias no IV Distrito transformaram consideravelmente, refletindo na variação de agentes sociais que estão inseridos nos processos de transformação do território. Os planos e projetos que tinham, até o PDDUA de 1999, o Estado como principal agente controlador da tomada de decisão, foram gradativamente abrindo espaço a novos agentes sociais, vinculados ao setor imobiliário e, mais recentemente, em especial a partir de 2016, articulando ações em colaboração com instituições de ensino, pesquisa e fomento à economia criativa.

Ações recentes evidenciam a flexibilização da legislação para favorecer a ação das empresas imobiliárias no espaço urbano de Porto Alegre: em 2019, através da lei complementar n. 850, os índices de venda de solo criado de médio adensamento (entre 300 e $1000 \mathrm{~m}^{2}$ ) passaram a ser adquiridos diretamente na prefeitura municipal. Os maiores beneficiados dessa alteração foram as construtoras Melnick Even e Cyrela, que compraram o correspondente a $46 \%$ do valor negociado junto à prefeitura, sendo $72 \%$ da quantidade efetiva e em andamento do solo criado correspondente à Macrozona 1, onde estão localizados o bairro Floresta e o Centro Histórico. Ademais, o regime volumétrico que incide sob o IV Distrito é condizente com a área destinada à revitalização e verticalização (AOI) do PDDUA de 2010, no qual são autorizadas as maiores alturas, entre 42 e $52 \mathrm{~m}$. A partir disso, é possível verificar o interesse do setor público em colaborar com o processo de verticalização e adensamento, imperativos da dinâmica imobiliária financeirizada. Além disso, o impacto de projetos subordinados ao mercado imobiliário e financeiro pode alterar consideravelmente a paisagem e vir a sobrecarregar a infraestrutura urbana já carente de manutenção. Outro importante destaque são os projetos de inovação tecnológica, principalmente com a criação do grupo denominado Pacto Alegre, ${ }^{4}$ em 2019, que articula instituições de ensino, governo, iniciativa privada e sociedade civil para estimular o empreendedorismo colaborativo, com destaque para representações das principais universidades do Estado (UFRGS, PUC/RS e Unisinos). Essas práticas revelam o interesse pela mudança 
na cidade voltada a um público específico: os novos significados sugeridos dão-se através de acordos entre Estado, mercado imobiliário e setores empresariais, que abrem a possibilidade de reestruturação produtiva, reconversão econômica e inclusão da área nos circuitos contemporâneos de investimento imobiliário da cidade, mas sem grandes preocupações com os moradores mais vulneráveis da cidade, distanciando-os ainda mais da cidade em que investe e consome.

Como resposta a essa ampliação do quadro de desigualdades na área, os problemas já existentes das habitações de interesse social se tornaram mais visíveis. 0 recente relatório desenvolvido pelo Conselho Estadual de Direitos Humanos (CEDH-RS), a partir da Missão em Defesa do Direito à Moradia e ao Trabalho Digno nas Ocupações Urbanas na Região do IV Distrito da Cidade de Porto Alegre/RS (2019), denuncia o silencioso processo de expulsão de comunidades pobres do território, viabilizado pelos despejos de famílias vulneráveis ou pela precarização do trabalho dos catadores de materiais recicláveis e dos galpões de reciclagem existentes na região.

Observando as ações articuladas entre o setor imobiliário e o Estado (através da prefeitura municipal), verifica-se o recorrente tensionamento das comunidades mais empobrecidas, deslocadas para áreas cada vez mais distantes do centro, em relação aos novos empreendimentos. No caso específico da área adjacente ao centro da cidade de Porto Alegre, as motivações para os deslocamentos das comunidades de baixa renda também estão vinculadas à inserção da metrópole e desse setor da cidade em um cenário local-global de desenvolvimento. Dado seu histórico de antigo setor industrial, fica evidente a intenção de atualização dos usos e ocupações da área para demandas mais próximas aos interesses econômicos vigentes, através da potencialização de serviços atrelados à indústria criativa e tecnológica que são comumente acionados em casos de reconversão econômica de antigos distritos industriais.

\section{0 perfil da produção habitacional no IV Distrito (2007-2016)}

Como visto no item anterior, as melhorias feitas pela prefeitura municipal de Porto Alegre, visando à preparação da cidade para as atividades da Copa do Mundo de 2014, tiveram entre os principais beneficiados o mercado imobiliário. Entre as empresas em destaque estão as construtoras Rossi Residencial S.A. e, mais recentemente, a MRV, que expandiram suas atividades nas cidades de origem e, atualmente, operam em diversos estados brasileiros e no Distrito Federal. ${ }^{5}$ Apesar de a data de entrada da empresa ser posterior à incorporação iniciada pela Rossi S.A., considera-se importante citar a contribuição da MRV para a dinâmica imobiliária da área, sobretudo por figurar junto à Rossi e outras relevantes empresas de construção civil do País que não atuaram em Porto Alegre, grandes beneficiadas do ciclo de abertura de capitais, intensificando suas atividades e aumentando seus lucros através da venda de unidades habitacionais do segmento econômico.

Quanto à atuação das empresas no IV Distrito, ressaltam-se os empreendimentos localizados no bairro Humaitá, nas proximidades do parque Mascarenhas de Moraes, 
cujas obras foram iniciadas por volta de 2010, havendo, ainda, algumas em processo de realização no perímetro. A descrição do parque aparece no site de divulgação do Condomínio Rossi Flora, junto aos detalhes dos apartamentos e do condomínio. 0 que à vista grossa pode parecer apenas uma descrição do entorno se transforma em dominação do espaço público, com o objetivo de promover interesses privados, sobretudo quando adicionados o recorrente risco de cercamento e a privatização de bens públicos. Acerca dos produtos imobiliários lançados nas imediações do Parque, estes são condomínios residenciais de dois ou três dormitórios, com área entre 50 e $70 \mathrm{~m}^{2}$, cujo valor de compra varia entre $\mathrm{R} \$ 250$ mil e $\mathrm{R} \$ 450$ mil, de acordo com o censo imobiliário elaborado pelo Sindicato das Indústrias da Construção Civil no estado do Rio Grande do Sul - Sinduscon, entre os anos de 2007 e 2016.

No Gráfico 1, construído a partir dos dados coletados e composto pelos números totais de unidades comerciais e habitacionais disponibilizadas para venda entre 2007 e 2016, podemos observar que: 1) os bairros Farrapos e Humaitá mantiveram-se sem novos produtos disponíveis para compra nos anos de 2007, 2009, 2010 e 2011; 2) em 2008, o bairro Humaitá apresentou 105 unidades; em 2012, 262; e, a partir de 2014, manteve-se ofertando unidades até apresentar seu pico, em 2016, com 195 unidades; 3) enquanto isso, o bairro

Gráfico 1 - Distribuição do número de unidades em oferta por bairros - 2007/2016

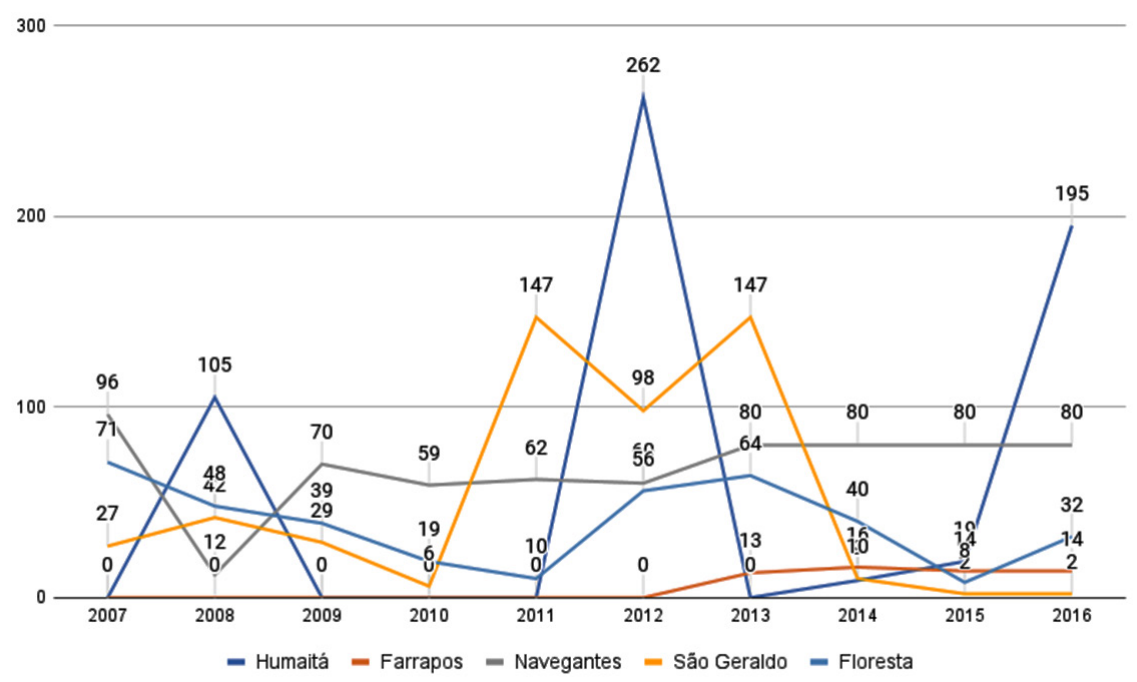

Fonte: Censo do Mercado Imobiliário de Porto Alegre - Sinduscon/RS, de 2007 a 2016.

Elaborado por Nicole Leal de Almeida, em 2021. 
Farrapos se manteve sem unidades ofertadas até 2013, quando passou a apresentar pouco mais de uma dezena de unidades por ano. Essa dinâmica demonstra que o bairro Farrapos não se tornou tão atrativo para o setor imobiliário, mesmo após a inauguração da Arena, em 2012, ao contrário do bairro Humaitá, que recebeu um número significativo de novas unidades habitacionais nos anos analisados. Com referência, ainda, ao bairro Farrapos, vale destacar que a maior parte dos EHIS construídos pelo Piec está localizada no bairro, além de diversos assentamentos precarizados e em situação indefinida. Com isso, podemos pressupor que a baixa incidência de novos produtos pode estar relacionada às áreas HIS que já foram regularizadas e que, por esse motivo, dificultam a remoção e diminuem a atração do mercado, por se tratar de uma área que não pode ser incorporada em grande escala e, sim, de forma fragmentada. Além disso, os assentamentos precários ainda existentes na região sofrem com o frequente tensionamento através de medidas judiciais de reapropriação de posse, despejo e reassentamento para áreas distantes do local de origem.

Observa-se ainda que, apesar de São Geraldo e Humaitá, de acordo com o Gráfico 1 , figurarem como responsáveis pelos maiores picos de disponibilidade de imóveis, no bairro Navegantes existe uma estabilidade representada por platôs e que resulta em um número superior aos demais de unidades habitacionais disponibilizadas. O bairro Floresta, por sua vez, apresenta uma peculiaridade em relação aos outros bairros: $79,84 \%$ dos imóveis disponibilizados para venda, entre os anos de 2007 e 2016, são identificados como salas comerciais ou lojas. Já, na Figura 2, verifica-se que a afinidade entre os bairros da extremidade norte se refere ao tipo de imóvel disponibilizado, porém, quando observados os números totais, confirma-se o isolamento do bairro Farrapos em relação aos demais. No que tange ao bairro Floresta, apesar do número de lançamentos habitacionais ser próximo ao do bairro Farrapos, o grande número de unidades comerciais confere, ao bairro, uma característica distinta dos demais. A distinção apresentada pelo bairro Floresta pode estar relacionada à sua proximidade com o centro histórico e com os bairros de alta renda, como é o caso do bairro Moinhos Vento, com o qual o bairro Floresta faz divisa.

Quando atribuímos, ao território, dados referentes ao valor do rendimento nominal médio das pessoas responsáveis e aos moradores em domicílios particulares permanentes, próprios e em aquisição (IBGE, 2010), percebemos o contraste entre as áreas de ocupação intensiva de incorporadoras em relação aos assentamentos precarizados e os EHIS realizados pelo Piec. É possível verificar que boa parte da população residente no entorno do empreendimento possui renda média de dois a quatro SM. ${ }^{6}$ Já a gleba que representa a área onde estão localizados os empreendimentos apresenta rendimento médio a partir de oito SM. Tendo como referência outros bairros da cidade de Porto Alegre, o trecho é compatível, no que se refere aos rendimentos, com áreas consideradas nobres pelo mercado imobiliário - Moinhos de Vento, Rio Branco, Petrópolis, Boa Vista, Mont'Serrat, Três Figueiras e Chácara das Pedras.

Diante disso, podemos dizer que a caracterização dos bairros analisados converge com a argumentação de Shimbo (2010). A autora aponta que a demanda por moradias atendida pelo segmento econômico não 
Figura 2 - Relação entre as unidades residenciais e comerciais disponibilizadas entre $2007 / 2016$

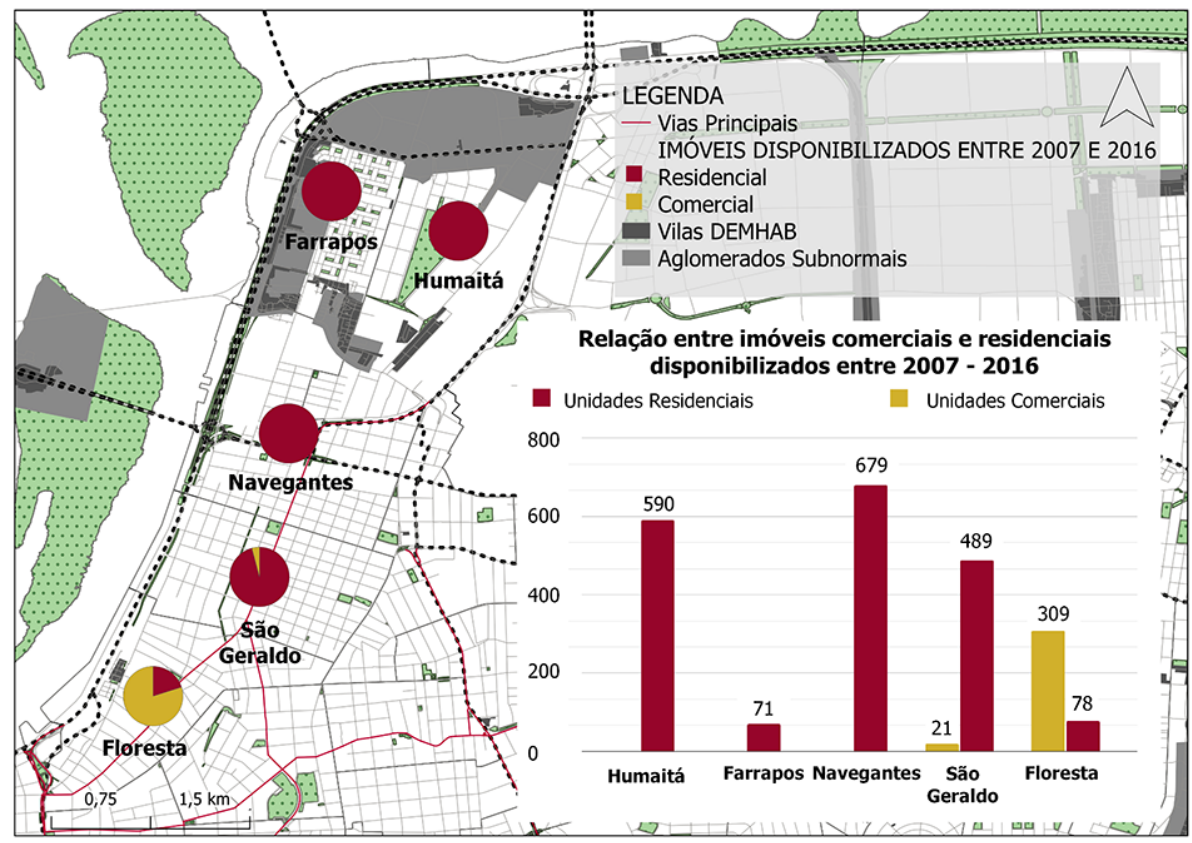

Fonte: Censo do Mercado Imobiliário de Porto Alegre - Sinduscon/RS, de 2007 a 2016. Elaborado por Nicole Leal de Almeida, em 2021.

corresponde ao déficit de moradias do País, apesar da conveniência em confundir habitação de interesse social com "habitação social de mercado", nos termos da autora. Ainda segundo Shimbo (ibid.), o déficit habitacional brasileiro corresponde, em maior parte, à população com renda familiar de até três SM, enquanto a população na faixa acima de cinco SM representa uma pequena parcela do déficit. No entanto, é justamente a faixa de cinco SM que apresenta maior retração do déficit através do seguimento econômico de mercado (ibid.). 0 que de fato se verifica no recorte espacial analisado, segundo o Relatório Missão em Defesa do Direito Humano à Moradia e ao Trabalho Digno nas Ocupações Urbanas na Região do 4을istrito da Cidade de Porto Alegre/RS (2019), organizado pelo Conselho Estadual de Direitos Humanos - CEDH, é que estão distribuídos 19 assentamentos entre o bairro Farrapos, no qual há a maior concentração de famílias, e o bairro Humaitá. A Figura 3 apresenta a localização desses assentamentos na área em análise. 
Figura 3 - Relação entre a renda nominal média mensal e a distribuição de assentamentos e vilas Demhab (Departamento Municipal de Habitação) e área de atuação concentrada das incorporadoras

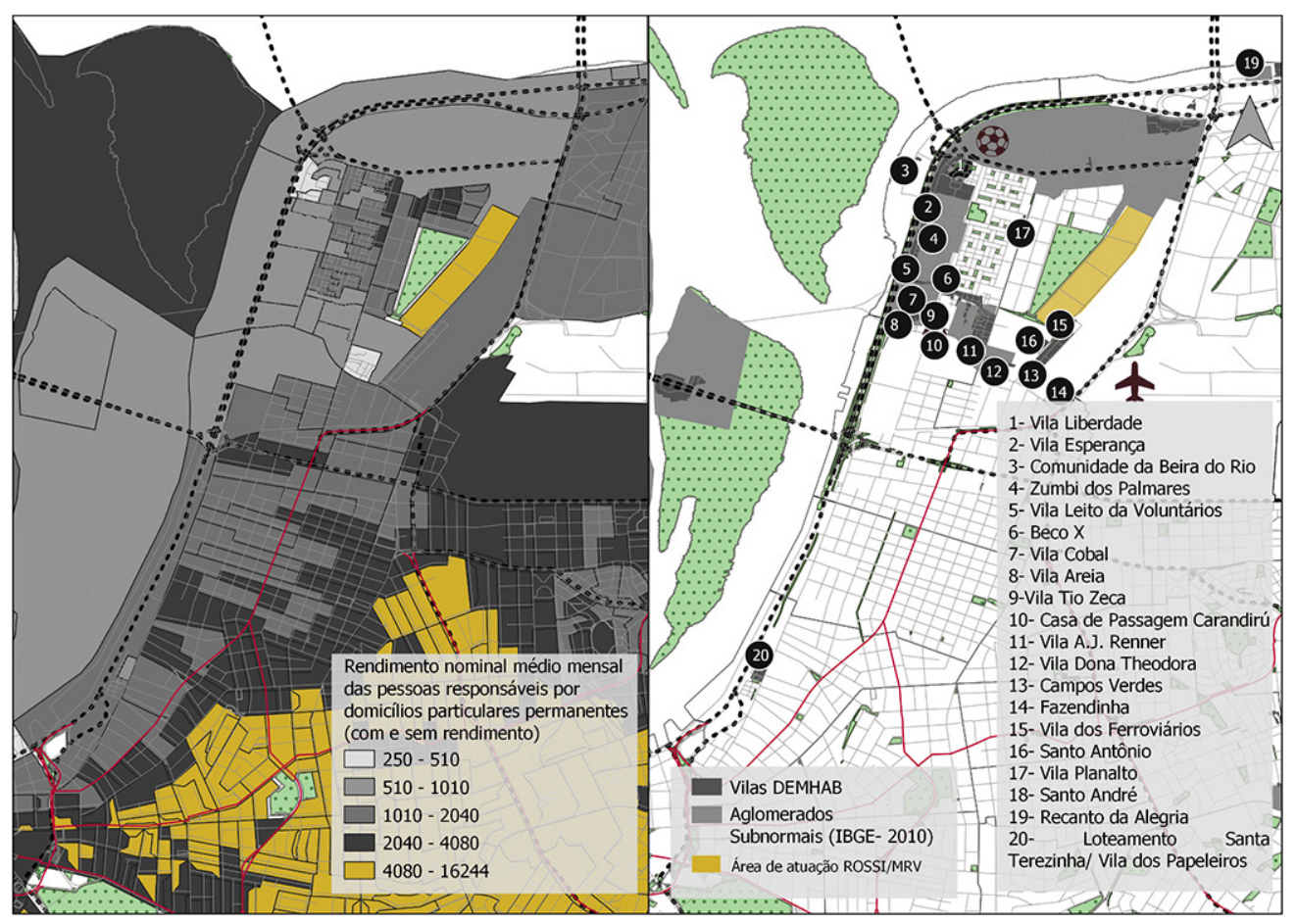

Fonte: Elaborado por Nicole Leal de Almeida, em 2021, a partir de dados disponibilizados pela Prefeitura Municipal de Porto Alegre (ObservaPOA, s/d).

Os assentamentos são ocupados por 1.900 famílias, que iniciaram a ocupação 5 anos antes da publicação do referido Relatório da Missão (2019), ou seja, em 2014; enquanto outros assentamentos já se encontram no local há pelo menos 30 anos, segundo o mesmo Relatório. Essa situação, no entanto, apresenta condições que indicam negligência por parte do poder público, visto que muitas famílias dessas ocupações já estão cadastradas em programas habitacionais e aguardam definições sobre seu reassentamento. Em alguns casos, as famílias que possuem recursos escassos não investem em melhorias nas suas casas, em geral, em situação precária, tendo em vista que não é viável, para a população, investir em espaços dos quais será despejada. Em outros casos, as famílias estão ameaçadas de despejo em ações de reintegração de posse, enquanto as áreas ocupadas que são consideradas Aeis sofrem com os espaçados investimentos, muitos realizados há mais de 15 anos. Além disso, os cadastros feitos pelo Demhab possuem mais de 20 anos e apresentam disparidades significativas em relação às demandas atuais. 
Nesse sentido, é evidente a pressão exercida sobre as famílias vulneráveis e empobrecidas para que se desloquem do IV Distrito, em que há uma atuação negligente do Estado em relação às necessidades e demandas do estrato social mais pobre, enquanto age como facilitador para a atuação do mercado imobiliário. Além da expulsão das famílias, através de medidas protetivas da propriedade privada, e da falta de compromisso com a providência de habitação de interesse social, enquanto direito fundamental estabelecido na Constituição Federal (1988), a prefeitura municipal atua em outras frentes de tensão contra a população vulnerável. 0 processo de expulsão corrente também opera sobre a geração de renda direta das famílias através de precarização do trabaIho de catadores de materiais recicláveis e dos galpões de reciclagem que existem na região, dificultando o processo de regularização desses galpões e fazendo a manutenção de propostas higienistas e positivistas que visam à proibição da circulação de catadores com carrinhos e carroças na cidade.

Na configuração, o que se apresenta são os limites históricos de acesso a infraestrutura e habitação digna em áreas urbanas sob as quais não esteja imposta a dominância da mercantilização da produção habitacional. Os programas habitacionais, a exemplo do Minha Casa Minha Vida (2009-2020), acabam beneficiando o mercado imobiliário, que se estrutura com rapidez para atender às demandas abertas. Enquanto isso, os estratos mais vulneráveis da população não são atendidos e são mantidos à margem, sob manutenção de baixos salários e da negligência do Estado. Para Rolnik (2019), o próprio termo, "aglomerado subnormal", oficialmente utilizado pelo Instituto Brasileiro de Geografia e Estatística (IBGE) para designar os assentamentos precários, é indício da discriminação social institucionalizada pelo próprio Estado. A autora ainda aponta que o destino de comunidades como estas parece estar condicionado à lógica da "destruição-remoção-erradicação" de espaços chamados informais.

Em contrapartida, os bairros que compõem o antigo distrito industrial de Porto Alegre, e que estão mais próximos ao centro histórico, também passam por um processo de transformação na ocupação e uso do solo. Enquanto os bairros Humaitá e Farrapos estão marcados por conflitos explícitos em relação ao uso do solo, com a intervenção do Estado com melhorias e flexibilização ao mercado imobiliário que visam à classe média e média baixa, os bairros São Geraldo e Floresta apresentam características mais próximas à reconversão econômica, através do mercado da economia criativa, da capitalização da cultura e de serviços voltados às classes média e alta.

Se, por um lado, a transformação da lógica imobiliária dos bairros Humaitá e Farrapos deu-se a partir da implantação da Arena, desencadeando uma leva de novos empreendimentos imobiliários, por outro é possível estabelecer, como marco na transformação e ressignificação dos bairros Navegantes e São Geraldo, a implantação do Residencial Rossi Fiateci. A construção do edifício Residencial Rossi Fiateci, anunciada em 2009, sustentava a promessa de ser um catalisador de revitalização em Porto Alegre, em especial no bairro São Geraldo. 0 edifício residencial localiza-se onde existiam as ruínas de uma das mais importantes fábricas da região, a Cia. Fiação de Tecidos Porto Alegrense - Fiateci, ${ }^{7}$ indústria que teve papel determinante para os arranjos do IV Distrito. Além de empregar centenas de 
operários e construir vilas operárias na região, Manoel Py, sócio e presidente da empresa, acumulava cargos no setor público e privado e também era um dos principais acionistas da Cia Predial e Agrícola, segundo Strohaecker (2005). A loteadora adquiriu, em 1902, a Companhia Territorial Porto Alegrense, que atuou principalmente na zona Norte da cidade, nos bairros Navegantes e São Geraldo. ${ }^{8}$

O empreendimento de uso misto, inaugurado em 2012, possui quatro torres, sendo três delas residenciais, que possuem denominações sugestivas à vinculação dos investimentos feitos no IV Distrito a conhecidos espaços reestruturados em antigas regiões industriais de importantes metrópoles mundialmente reconhecidas: Soho, Tribeca e Puerto Madero. Ao remeter o projeto no setor gaúcho, assume um padrão de forma e estética reproduzido em várias cidades do mundo e distantes do que seu contexto oferece. Além disso, essas novas construções com antigas estratégias de refuncionalização, segundo Carlos (2015), conformam uma imagem de modernização vinculada à ordem neoliberal vigente, como é o caso do IV Distrito, tornando-se visadas para novos investimentos pela quantidade de terrenos e edificações vagos, passíveis de serem incorporados ao mercado imobiliário.

A disponibilidade de áreas por baixo custo, entretanto, não é suficiente para requalificar setores da cidade, como visto no caso dos bairros Farrapos e Humaitá. A interferência do Estado através de investimentos e flexibilização da legislação, além do contexto do mercado financeiro e imobiliário nacional, foi o ponto inicial da movimentação do mercado imobiliário na região. Carlos (ibid., p. 27) aponta que a intervenção do Estado, através do poder local, é determinante para o processo de hierarquização de setores da cidade, "criando novas centralidades, expulsando para a periferia os antigos habitantes e recriando um espaço de dominação". No caso dos bairros Navegantes, São Geraldo e Floresta, a movimentação do mercado imobiliário é sempre mediada pela reorganização dos espaços e seus significados tradicionais.

A ressignificação do setor traz a reboque a produção de uma nova sociabilidade, ou seja, uma nova forma de se apropriar da cidade através de espaços construídos como desejo de consumo, que possam se encaixar em novas necessidades (Padua, 2015). Nesse sentido, destaca-se a utilização de antigos galpões e casarões abandonados para acomodar cervejarias, bares e restaurantes. A escolha dos imóveis dá-se pelo baixo custo e pela estrutura ampla, tendo em vista suas antigas funções industriais, além do potencial de uso da estrutura existente como diferencial estético, corroborando as colocações de Carlos (2015) de que as redefinições do espaço refletem nas relações sociais, conforme o uso e as funções dos bairros se transformam.

A economia criativa é um exemplo de ressignificação do uso da área, além dos padrões de habitação e uso corporativo. Uma das iniciativas mais marcantes para o IV Distrito deu-se a partir do reuso do complexo arquitetônico vila Flores, projetado em 1928 pelo arquiteto José Franz Seraph Lutzenberger e, atualmente, administrado pelos proprietários, a família Wallig. A abertura do complexo, a empresários e artistas, para as atividades de economia criativa, apoia-se em quatro pilares: arte e cultura, arquitetura e urbanismo, educação e empreendedorismo social e criativo. ${ }^{9}$ A associação também organiza trabalhos de forma colaborativa com outros coletivos da 
região, que lutam por melhores condições de vida e de trabalho para os catadores, e com o Assentamento 20 de Novembro, em que aproximadamente 40 famílias ocupam o edifício da União, construído para ser um hospital e abandonado há mais de 50 anos. Considerando as ações colaborativas entre a Associação Vila Flores e coletivos de luta por trabalho digno e moradia da região, observa-se que, apesar de o mercado imobiliário ter a seu favor a hegemonia das relações para se apropriar de iniciativas independentes, núcleos de trabalho colaborativo junto às comunidades tentam fortalecer a autonomia dos bairros.

Contudo, Harvey (2014, p. 153) observa que "quanto melhores as qualidades comuns que um grupo social cria, mais provável é que sejam tomadas de assalto e apropriadas por interesses privados de maximização de lucros". Isso fica evidente na pesquisa de Cardoso (2017) que, através da análise de matérias veiculadas em um jornal local, entre 2009 e 2016, observou a construção de uma narrativa sobre o IV Distrito que antecedeu à espacialidade das transformações promovidas pela economia criativa. Nas primeiras incursões analisadas pela autora, entre 2009 e 2013, a economia criativa é apresentada como uma possibilidade para o crescimento econômico, corroborada por ações do Estado, pesquisas técnicas e relatos de especialistas estrangeiros. Em 2012, segundo a autora, são noticiadas a implantação da Associação Cultural Vila Flores, inaugurada no mesmo ano, além da recuperação de seu conjunto arquitetônico. Essas iniciativas convergem com a reflexão de Arantes (2013), que ressalta o processo de revalorização urbana e patrimonial associado à rentabilidade, além de atrelado ao patrimônio arquitetônico-cultural, tornando-se este um aliado do mercado imobiliário.
Ainda segundo Cardoso (2017), foi a partir de 2014 que se verificou a inserção da ideia de recuperação do espaço através da economia criativa nas narrativas jornalísticas. Entre 2014 e 2015, a autora identificou a concentração dos esforços por parte do jornal local analisado para instaurar uma identidade vinculada à economia criativa e justificada pelas ações de artistas e empreendedores locais. A recuperação do espaço e a ideologia do crescimento, para Molotch (1976), encontram suporte da população local quando atrelam o crescimento ao surgimento de trabalho. Entretanto, não há garantias de que a população local será beneficiada, sobretudo considerando-se a construção da identidade criativa alheia aos residentes da área. Molotch (ibid.) aponta também que ações governamentais têm papel fundamental para aumentar o potencial de crescimento da área, ajudando a determinar custos e acesso.

Nessa lógica, os esforços identificados na construção da narrativa da revalorização urbana e patrimonial, para Cardoso (2017), foram viabilizados através da proposta de isenção de Imposto sobre a Propriedade Predial e Territorial Urbana (IPTU), pelo período de cinco anos, para empresas de base tecnológica, inovadoras e de economia criativa instaladas nos bairros Floresta, São Geraldo, Navegantes, Humaitá e Farrapos; conferindo, a construção da identidade pelas mídias locais, legitimação legal e corroborando a argumentação posta por Molotch (1976). Em 2016, Cardoso (2017) considera que a espacialidade do IV Distrito já está constituída e passa por um momento de reafirmação, dadas a proximidade com as eleições municipais e a incerteza a respeito das políticas públicas para o setor da economia, considerando a possibilidade de extinção do 
Ministério da Cultura e da Secretaria da Economia Criativa vinculada a ele. ${ }^{10}$ Observa-se, a partir da sistematização elaborada por Cardoso (2017), a construção de uma narrativa alinhada à potencialização de uma determinada imagem para o IV Distrito. Para Arantes (2013), o uso da cultura como ferramenta de identificação de indivíduos e coletividades com o espaço está associado ao "culturalismo de mercado". Entende-se que a homogeneização dos diversos espaços do IV Distrito, através de uma identidade construída por motivações associadas ao consumo e pela distinção associada ao capital cultural, confere à cidade status de mercadoria.

Na esteira da reestruturação do IV Distrito, através da sua ressignificação, em 2019 a Secretaria de Cultura de Porto Alegre anunciou que o Museu de Arte Contemporânea/RS teria sua sede própria. A nova sede fica localizada no bairro Floresta, em terreno doado pelo Estado, a poucas quadras do complexo que abriga o vila Flores e visa à estruturação do território através da interação entre outros pontos da cultura criativa. A divulgação no site do museu destaca que as intenções com a implantação de um museu naquele setor da cidade são provenientes da capacidade de o espaço cultural "transcender à sua sede" e "ser ocupado pela comunidade, transformando, aos poucos, o próprio IV Distrito em um Museu vivo e aberto às manifestações contemporâneas de arte, cultura e ação social". ${ }^{11}$

Entretanto, equipamentos culturais utilizados como intervenção urbana poderiam estar aliados às demandas sociais do território através de estratégias concretas. Ações culturais que não promovem a autonomia comunitária acabam por se dissolver entre as tentativas de ressignificação e aproximação de agentes por tomada de posições através do acúmulo de capital cultural. Tendo em vista que o espaço social é construído de tal modo que os agentes sociais ou grupos são distribuídos em função dos princípios de diferenciação, como capital econômico e cultural, as distâncias sociais acabam reforçando distâncias espaciais (Bourdieu, 1996). Dessa forma, o que se observa é a apropriação do mercado imobiliário no lançamento de produtos que se alinhem às práticas cotidianas legitimadas pelo capital, enquanto distinguem e agrupam agentes que não atuam no espaço as qualidades determinadas.

\section{Considerações finais}

Neste artigo, discutiu-se o papel dos bairros adjacentes ao centro como setores de reserva de investimentos na cidade, ao passarem por períodos cíclicos e mais longos de degradação e revalorização urbana por meio de investimentos feitos pelo Estado e pelo capital imobiliário, sendo a política habitacional um importante mecanismo de sua transformação física e social. Essas transformações afetam não apenas os espaços degradados e abandonados, mas principalmente a população mais vulnerável que ali habita.

A transformação do espaço das áreas adjacentes ao centro, segundo Carlos (2015), enquanto adaptação dos ciclos econômicos da própria cidade, apresenta a capacidade de renovação de determinados setores das metrópoles, renovação esta que tende a condicionar o processo de hierarquização dos espaços, aprofundando as desigualdades sociais e espaciais. Carlos (ibid.) também destaca que, 
dos conflitos que decorrem de estratégias divergentes na produção do espaço e sua permanente transformação, nascem lutas que evidenciam as contrariedades postas no jogo das relações sociais e na legitimação de quem pode ocupar a cidade. 0 que se apresenta, a partir desse contexto, é a dominância da economia neoliberal em estruturas cada vez mais essenciais para a vida humana, serviços públicos e de infraestrutura que vêm sendo substituídos por práticas empreendedoras, que colocam todos os indivíduos como os únicos responsáveis por suas vidas (Butler, 2018).

O caso analisado, IV Distrito de Porto Alegre, envolve distintas manifestações da dinâmica imobiliária nos cinco bairros que o compõem, em uma privilegiada localização urbana: às margens do principal eixo metropolitano (BR-116 e Trensurb) de acesso à cidade. Destinado à localização das primeiras indústrias do Rio Grande do Sul no final do século XIX, essa foi sua função principal até o fim da primeira metade do século XX. Seu processo de obsolescência e degradação, a exemplo de outras situações em metrópoles brasileiras, ocorreu dos anos 1970 até meados dos anos 1990, quando interesses de reconversão econômica começaram a ser construídos pelo poder público, com o suporte do capital imobiliário e da mídia local. Atualmente, o IV Distrito possui distintas características que coexistem: população de baixa renda que ocupa assentamentos precários, vazios urbanos em terrenos de antigas indústrias e empreendimentos imobiliários residenciais vinculados à construção do estádio Arena do Grêmio.

Essa convivência, nem sempre pacífica, revela marcas de diferentes momentos em que os diversos agentes participam do cotidiano do setor, com claro suporte do poder público aliado a interesses de investimento do capital imobiliário. Contudo, torna-se evidente, ao longo das análises, que, mesmo com suporte do poder público, áreas em situação de vulnerabilidade não se tornaram interessantes ao setor privado. Como é o caso do bairro Farrapos, onde está localizada a Arena do Grêmio e um dos principais acessos à cidade. A realidade das famílias em situação de vulnerabilidade situadas na área diverge muito dos crescentes investimentos imobiliários que têm ocorrido ou que são previstos para a maior parte dos bairros que compõem o IV Distrito. Os assentamentos precarizados em que habitam poderiam ser contemplados através de contrapartidas e mitigações advindas da construção de novos empreendimentos e investimentos imobiliários. No entanto, tais espaços permanecem suscetíveis às pressões relacionadas, direta ou indiretamente, à dinâmica imobiliária vigente, bem como à própria política urbana desenvolvida ao longo da história de Porto Alegre.

O que se verifica é a potencialização de conflitos e constantes disputas que irrompem através de medidas de reapropriação de posse, ordens de despejo e reassentamento para áreas distantes do local de origem. Ademais, está em curso o processo de liberação da Carta de Habitação referente às torres habitacionais já construídas junto à Arena, o que, pressupõe-se, trará impactos significativos ao bairro. 0 caso analisado é revelador quanto à participação de decisões do Estado, em sua esfera municipal, na dinâmica econômica e social do IV Distrito, pois dele partem decisões e leis que viabilizam essas transformações de uso e ocupação do solo. A referência presente na área a antigos modelos internacionais de revitalização urbana compõe intervenções 
dissociadas, funcional e morfologicamente, da realidade de seu entorno, rompendo com linguagens e informações sobre um passado recente da cidade.

Por fim, é importante destacar que, apesar do amplo poder de atuação dos agentes dominantes, os movimentos sociais e grupos culturais locais têm encontrado formas de resistir através de práticas insurgentes e com senso de coletividade. São essas práticas, com origem nas lutas da sociedade, que contestam a dinâmica dominante e exigem atenção e estudos próprios, a fim de contribuir para que novos arranjos sejam possíveis.

\section{[I] https://orcid.org/0000-0002-9744-3806}

Universidade Federal do Rio Grande do Sul, Faculdade de Arquitetura, Programa de Pós-Graduação em Planejamento Urbano e Regional. Porto Alegre, RS/Brasil.

nlealdealmeida@gmail.com

\section{[II] https://orcid.org/0000-0002-2789-3887}

Universidade Federal do Rio Grande do Sul, Faculdade de Arquitetura, Departamento de Urbanismo, Programa de Pós-Graduação em Planejamento Urbano e Regional. Porto Alegre, RS/Brasil. heleniza.campos@gmail.com

\section{Notas}

(1) Segundo Royer (2009, p. 73), entre 2007 e 2008, as contratações de recursos do SBPE (Sistema Financeiro de Habitação) atingiram o ápice e são resultado, em boa parte, da atuação do governo federal com a melhoria do ambiente regulatório e do crédito para pessoa física.

(2) A cidade de Porto Alegre foi dividida em distritos e permaneceu assim até 1957, quando passou a ter como referencial territorial a divisão por bairros. Os bairros citados faziam parte do IV Distrito, caracterizado como o mais adequado para sediar funções industriais.

(3) O município foi governado pelos seguintes partidos: Alceu Collares (PDT, de 1986 a 1988); Olívio Dutra (PT, de 1989 a 1993); Tarso Genro (PT, de 1993 a 1997); Raul Pont (PT, de 1997 a 2001); Tarso Genro e João Verle (PT, de 2001 a 2005); José Fogaça (PPS/PMDB, de 2005 a 2010); José Fortunati (PDT, de 2010 a 2017); Nelson Marchezan Jr (PSDB, de 2017 a 2021; e, atualmente, Sebastião Melo (MDB).

(4) Ver descrições e projetos em: https://pactoalegre.poa.br. Acesso em: 11 mar 2021. 
(5) Segundo informações de Shimbo (2010), já na década de 1990 a empresa Rossi S.A. identificou carências de financiamentos destinados ao segmento econômico e lançou o "Plano 100" e o "Vida Nova", voltados às classes média e baixa. A MRV, por sua vez, iniciou a sua atuação nos anos 1970 e concentrou suas atividades exclusivamente em "Empreendimentos Residenciais Populares".

(6) Para referência de cálculo, foi considerado o salário-mínimo em vigência em 2010, ano em que foi realizado o censo de 2010, utilizado como base de dados.

(7) A empresa foi fundada em 6 de agosto de 1981, em Porto Alegre, por Manoel Py. Informação disponível em: https://fiateci.com.br/. Acesso em: 11 mar 2021.

(8) Maiores informações sobre os desdobramentos da atuação das companhias de loteamento no mercado de terras de Porto Alegre (1890-950) estão disponíveis em Strohaecker (1985 e 2005).

(9) Acreditamos no poder da conexão entre as pessoas para transformar o mundo. Vila Flores. Disponível em: http://vilaflores.org/. Acesso em: 11 mar 2021.

(10) O Ministério da Cultura foi oficialmente extinto em 1 을 de janeiro de 2019, pela medida provisória n. 870, publicada em edição especial do Diário Oficial da União.

(11) Museu de Arte Contemporânea RS terá sede própria em 2020. Amigos do Macrs. Porto Alegre, 2019. Disponível em: https://amigosdomacrs.com.br/sede-iv-distrito/ Acesso em: 24 mar 2021.

\section{Referências}

AALBERS, M. (2015). “Corporate Financializations". In: CASTREE, N. et al. (orgs.). The International Encyclopedia of Geography: people, the earth, environment and technology. Oxford, Wiley.

ALBANO, M. T. F. (2015). Quarto Distrito em Porto Alegre: reconhecimento da área e algumas referências. Disponível em: http://lproweb.procempa.com.br/pmpa/prefpoa/inovapoa/usu_ doc/s8.pdf. Acesso em: 22 fev 2021.

ARANTES, O. (2013). "Uma estratégia fatal: A cultura nas novas gestões urbanas". In: ARANTES, O.; VAINER, C.; MARICATO, E. (orgs.). A cidade do pensamento único: desmanchando consensos. Petrópolis, Vozes.

BOURDIEU, P. (1996). Razões práticas: sobre a teoria da ação. Campinas, Papirus.

BURGESS, E. (1974). "El crecimiento de la ciudad: introducción a un proyecto de investigación". In: THEODORSON, G. A. (coord.). Estudios de Ecologia Humana. Barcelona, Labor, pp. 69-81.

BUTLER. J. (2018). Corpos em aliança e a política das ruas: notas para uma teoria performativa de assembleia. Rio de Janeiro, Civilização Brasileira.

CARDOSO, A. L.; ARAGÃO, T. A. (2011). "A reestruturação do setor imobiliário e o Programa Minha Casa Minha Vida”. In: MENDONÇA, J. G; COSTA, H. S. M. (orgs.). Estado e Capital Imobiliário: Convergências atuais na produção do espaço urbano brasileiro. Belo Horizonte, C/Arte. 
CARDOSO, R. C. (2017). Espaços criativos: a configuração de uma espacialidade pela narrativa jornalística. Dissertação de mestrado. Porto Alegre, Universidade Federal do Rio Grande do Sul.

CARLOS. A. D. A. (2015). "A reprodução do espaço urbano como momento da acumulação capitalista”. In: CARLOS, A. D. A. (org.). Crise urbana. São Paulo, Contexto.

CORRÊA, R. L. (1989). O espaço urbano. São Paulo, Ática.

FERNANDES, A. C. (2014). Cemitérios industriais: contribuição para a análise espacial da metrópole de Porto Alegre - RS/ Brasil. Tese de doutorado. Porto Alegre, Universidade Federal do Rio Grande do Sul.

FIX, M. A. D. (2011). Financeirização e transformações recentes no circuito imobiliário no Brasil. Tese de doutorado. Campinas, Universidade Estadual de Campinas.

HARVEY, D. (2014). Cidades rebeldes: do direito à cidade à revolução urbana. São Paulo, Martins Fontes.

IBGE - Instituto Brasileiro de Geografia Estatística (2010). Resultados do universo. Disponível em: <https://ftp.ibge.gov.br/Censos/Censo_Demografico_2010/Resultados_do_Universo/Agregados_ por_Setores_Censitarios/RS_20171016.zip> Acesso em: 15 maio 2021.

MATTAR, N. L. (2010). A modernidade de Porto Alegre: arquitetura e espaços urbanos plurifuncionais em área do 4o Distrito. Tese de doutorado. Porto Alegre, Pontifícia Universidade Católica do Rio Grande do Sul.

MIRON, G. I. L. (2008). Gerenciamento dos requisitos dos clientes de empreendimentos habitacionais de interesse social: proposta para o programa integrado entrada da cidade em Porto Alegre/RS. Tese de doutorado. Porto Alegre, Universidade Federal do Rio Grande do Sul.

MOLOTCH, H. (1976). The city as a growth machine: toward a political economy of place. American Journal of Sociology. Published by The University of Chicago Press, v. 82, n. 2, pp. 309-332.

MPRS (2020). Firmado o acordo preliminar para a execução das obras no entorno da Arena. Ministério Público Estado do Rio Grande do Sul. Porto Alegre, 17 nov. Disponível em: https://www.mprs. mp.br/noticias/52319/. Acesso em: 2 mar 2021.

OBSERVAPOA - Observatório da Cidade de Porto Alegre (s/d). Equipamentos e Serviços. Disponível em: < http://observapoa.com.br/default.php?reg=278\&p_secao=46>. Acesso em: 26 maio 2021.

PADUA, R. (2015). “Produção estratégica do espaço e os 'novos produtos imobiliários'”. In: CARLOS, A. F. A; VOlOCHKO, D.; ALVAREZ, I. P. (orgs.). A cidade como negócio. São Paulo, Contexto.

PMPA (2008). Grupo de Trabalho do 4을 Distrito. Disponível em: http://www2.portoalegre.rs.gov.br/ spm/default.php?p_secao=150. Acesso em: 22 fev 2021.

(2009). Plano Municipal de Habitação de Interesse Social. Departamento Municipal de Habitação. Porto Alegre. Disponível em: http://lproweb.procempa.com.br/pmpa/prefpoa/ demhab/usu_doc/diagnstico_porto_alegre.pdf Acesso em: 22 fev 2021.

(2011). Plano Diretor de Desenvolvimento Urbano Ambiental de Porto Alegre. Porto Alegre. Disponível em: https://www2.portoalegre.rs.gov.br/spm/default.php?p_secao=205. Acesso em: 22 fev 2021.

ROLNIK, R.; CYMBALISTA, R.; NAKANO, K. (2011). Solo urbano e habitação de interesse social: a questão fundiária na política habitacional e urbana do país. Revista de Direito da ADVOCEF. Brasília, ano VII, n. 13, pp. 123-158. 
ROLNIK, R. (2015). Guerra dos lugares: a colonização da terra e da moradia na era das finanças. São Paulo, Boitempo.

(2019). Paisagens para renda, paisagens para vida: disputas contemporâneas pelo território urbano. Revista Indisciplinar. Belo Horizonte, v. 5, n. 1, pp. 18- 43.

ROYER, L. O. (2009). Financeirização da política habitacional: limites e perspectivas. Tese de doutorado. São Paulo, Universidade de São Paulo.

SHIMBO, L. Z. (2010). Habitação social, habitação de mercado: a confluência entre estado, empresas construtoras e capital financeiro. Tese de doutorado. São Carlos, Universidade de São Paulo.

SINGER, P. (1977). Desenvolvimento econômico e evolução urbana. São Paulo, Companhia Editora Nacional.

(2017). Urbanização e desenvolvimento. Belo Horizonte, Autêntica; São Paulo, Fundação Perseu Abramo.

SOUZA, C. F. DE; MÜLLER, D. M. (1997). Porto Alegre e sua evolução urbana. Porto Alegre, Editora da UFRGS.

STROHAECKER, T. M. (1988). A zona periférica ao centro: uma revisão bibliográfica. Revista Brasileira de Geografia. Rio de Janeiro, ano 50, n. 4. pp. 171-183.

(2005). Atuação do Público e do privado na estruturação do mercado de terras de Porto Alegre (1890-1950). Disponível em: http://www.ub.edu/geocrit/sn/sn-194-13.htm. Acesso em: 22 fev 2021.

TITTON, P. C. (2012). Reestruturação produtiva e regeneração urbana: o caso do IV Distrito de Porto Alegre. Dissertação de mestrado. São Paulo, Universidade Presbiteriana Mackenzie.

Texto recebido em 31/mar/2021

Texto aprovado em $27 /$ jun/2021 